\title{
A 5-year review of maternal mortality associated with eclampsia in a tertiary institution in northern Nigeria
}

\author{
Abubakar Ali Kullima, Mohammed Bello Kawuwa, Bala Mohammed Audu' ${ }^{1}$ Hadiza Usman ${ }^{1}$, \\ Ado Danazumi Geidam ${ }^{1}$ \\ Department of Obstetrics and Gynaecology, Federal Medical Centre Nguru, 'Department of \\ Obstetrics and Gynaecology, University of Maiduguri Teaching Hospital, Nigeria
}

Correspondenceto: Dr. A A Kullima, Department of Obstetrics and Gynaecology, Federal Medical Centre, Nguru PMB 02, NguruYobe State. E-mail: drkullima@ yahoo.com

\begin{abstract}
Objective:To determine the incidence of maternal mortality associated with eclampsia and to determine how sociodemographic and clinical characteristics of the women influence the deaths.

Methodology: Records of 52 eclampsia-related mortalities from January 2003 to December 2007 were reviewed, retrospectively. Their social demography, mode and place of delivery, time of eclampsia, and fetal outcome were extracted for analysis.

Results: Eclampsia accounted for 52 (46.4\%) of the 112 total maternal deaths recorded within the 5-year period, with case fatality of $22.33 \%$. Age group $<20,20-29$ and above 30 all had similar case fatality rate of $22.1 \%, 23.8 \%$ and $26.7 \%$, respectively. Those who were experiencing their first deliveries have the worst deaths recording $42.5 \%$ of the case fatality in that category. As expected, unbooked had higher case fatality of $24.0 \%$ compared to $15 \%$ among booked cases, while those with no formal education also had more death ( $22.3 \%$ case fatality) as compared to $3.3 \%$ among those who had some form of formal education. Antepartum eclampsia was the cause in $50 \%$ of the death, $11(21.2 \%)$ of the pregnancies were not delivered before their death, while $18(34.6 \%)$ were stillbirth.

Conclusion: Eclampsia still remains the major cause of maternal mortality in this region resulting from unsupervised pregnancies and deliveries. There is need to educate and encourage the general public for antenatal care and hospital delivery.
\end{abstract}

Keywords: Eclampsia, maternal mortality, northern Nigeria

\section{Résumé}

objectif: pour déterminer l'incidence de la mortalité maternelle associés à éclampsie et pour déterminer comment caractéristiques sociodémographiques et cliniques de l'influence de femmes le décès.

méthodologie: dossiers de de 52 éclampsie mortalité connexe de janvier 2003 - décembre 2007 ont été examinées rétrospectivement. Leur démographie sociale, la mode et le lieu de livraison, temps de éclampsie et le résultat du foetus ont été extraits pour analyse.

résultats: éclampsie ont représenté $52(46.4 \%)$ de décès maternels total 112 enregistrés dans les cinq ans période, en cas de décès de $22.33 \%$. groupe d'âge <20, all 20-29 et au-dessus de 30 avait même taux de létalité de $22.1 \%$, de 23,8 $\%$ et de $26,7 \%$ respectivement. Ceux qui éprouvaient leurs premières livraisons ont les pires décès enregistrement $42,5 \%$ de l'affaire accidents mortels dans cette catégorie. Comme prévu unbooked avait supérieur cas de décès de 24,0\% comparativement à $15 \%$ parmi les cas un avertissement, alors que celles sans aucune l'éducation formelle a également eu plusieurs décès (22,3\% cas mortel) par rapport à 3,3\% Parmi ceux qui avaient une forme de l'éducation formelle. Antepartum éclampsie a été la cause de $50 \%$ de la mort, $11(21.2 \%)$ de la grossesse n'étaient pas livrés avant leur mort, alors que 18 (34,6\%) ont été mortinaissance.

conclusion: éclampsie demeure toujours la principale cause de mortalité maternelle dans cette région résultant 
sans surveillance grossesses et les livraisons. Il est nécessaire éduquer et encourager le general public de prestation de soins et des hôpitaux prénatals.

Mots cles: éclampsie, la mortalité maternelle, Nord du Nigeria

DOI: $10.4103 / 1596-3519.56233$

PMID: 19805936

\section{Introduction}

Eclampsia remains a complication of pregnancy and a leading contributor to maternal and perinatal morbidity and mortality. ${ }^{[1,2]}$ Worldwide ${ }^{[3]}$ it accounts for 50,000 maternal deaths annually. In spite of the several global and regional interventions and initiatives from governments and other concerned agencies, maternal mortality continues to rise in subSaharan Africa with eclampsia as a major cause. ${ }^{[4,5]}$ Over the last decade it remained the leading cause of maternal and perinatal mortality in Nigeria, ${ }^{[6-8]}$ This picture could even be worse especially in the northeastern part of Nigeria with so far, the worst case fatality rate of $11.6 \%(11,600 / 100,000)$ as reported in Gombe. ${ }^{[9]}$ This study was undertaken to determine the incidence of eclampsia-related death in the study population, the socio-demographic characteristic of the women and pregnancy outcome.

\section{Materials and Methods}

This is a retrospective study of maternal deaths from eclampsia recorded in Federal Medical Centre Nguru over a 5-year period, from January 1, 2003 to December 31, 2007. Out of the 112 total maternal deaths recorded over the study period, records of 52 patients who suffered from eclampsia-related deaths were retrieved from the medical records library, and information pertaining to their age, parity level of education and booking status was obtained. Information on the mode of delivery, time of eclampsia, fit controlled and gestational age at delivery, place of delivery, and fetal outcome were also obtained from the records for analysis using SPSS version 11. The Chi-square test was used for test of significance.

\section{Results}

During the period under review, a total of 3931 deliveries were recorded, 224 cases had eclampsia, giving a prevalence rate of $5.7 \%$ of the total deliveries. Diazepam is the sole anticonvulsant used for all the cases. Total deaths from eclampsia were 52 out of the 112 maternal death over the same period accounting for $46.4 \%$ of the total maternal death and a case fatality rate of $22.3 \%(22,300 / 100,000)$ and eclampsia-related maternal mortality ratio (MMR) of 1322/100,000 deliveries. As shown in Table 1, age group <20, 20-29, and above 30 all had similar case fatality rate of $22.1 \%, 23.8 \%$, and $26.7 \%$, respectively. Those who were experiencing their first deliveries have the worst deaths recording $42.5 \%$ of the case fatality in that category. As expected, unbooked had higher case fatality of $24.0 \%$ compared to $15 \%$ among booked cases, while those with no formal education also had more death ( $22.3 \%$ case fatality) as compared to $3.3 \%$ among those who had some form of formal education.

Table 2 illustrates the type of eclampsia and delivery outcome. About $50 \%$ of the victims had ante-partum eclampsia, while intrapartum and postpartum eclampsia were found among $34.6 \%$ and $15.4 \%$, respectively. Surprisingly, $80.5 \%$ of the eclamptics delivered within the hospital environment, and $19.5 \%$ were cases of postpartum eclampsia and whose deliveries were conducted at home. Of those whose deliveries that were conducted in the hospital preterm and term deliveries were proportionally similar, but in majority the gestational age were estimated based on the fundal height at the time of presentation rather than by date or with the use of ultrasound scan. Spontaneous vaginal delivery, assisted vaginal delivery, and caesarean section were the modes of delivery of the pregnancies in 17 $(32.6 \%), 15(28.8 \%)$, and $9(17.3 \%)$, respectively. Fit controlled was achieved in $47(90.4 \%)$ of the cases,

\begin{tabular}{lccc}
\hline \multicolumn{4}{l}{ Table 1: Socio-demographic characteristics } \\
\hline Age group & $\begin{array}{c}\text { Cases of } \\
\text { eclampsia }\end{array}$ & $\begin{array}{c}\text { Number } \\
\text { of death }\end{array}$ & $\begin{array}{c}\text { Case fatality } \\
(\%)\end{array}$ \\
\hline$<20$ & 104 & 23 & 22.1 \\
$20-29$ & 105 & 25 & 23.8 \\
$30-39$ & 15 & 4 & 26.7 \\
Total & 224 & 52 & \\
Parity & & & \\
1st delivery & 80 & 34 & 42.5 \\
2-4 & 111 & 13 & 11.7 \\
Above 5 & 33 & 5 & 15 \\
Total & 224 & 52 & \\
Literacy level & & & \\
Yes & 30 & 1 & 3.3 \\
No & 194 & 51 & 22.3 \\
$\quad$ Total & 224 & 52 & \\
Prenatal care & & & \\
Yes & 20 & 3 & 15 \\
$\quad$ No & 204 & 49 & 24.0 \\
Total & 224 & 52 & \\
\hline
\end{tabular}




\begin{tabular}{|c|c|c|c|c|c|c|}
\hline \multicolumn{3}{|c|}{ Time of eclampsia } & \multicolumn{2}{|c|}{$\begin{array}{c}\text { Number of } \\
\text { death }\end{array}$} & \multicolumn{2}{|c|}{$\%$} \\
\hline \multicolumn{3}{|c|}{ Ante-partum } & \multicolumn{2}{|c|}{26} & \multicolumn{2}{|c|}{50} \\
\hline \multicolumn{3}{|c|}{ Intrapartum } & \multicolumn{2}{|r|}{18} & \multicolumn{2}{|c|}{34.6} \\
\hline \multicolumn{3}{|c|}{ Postpartum } & \multicolumn{2}{|r|}{8} & \multicolumn{2}{|c|}{15.4} \\
\hline \multicolumn{7}{|c|}{ Place of delivery } \\
\hline \multicolumn{3}{|c|}{ Home } & \multicolumn{2}{|r|}{8} & \multicolumn{2}{|c|}{19.5} \\
\hline \multirow{2}{*}{\multicolumn{3}{|c|}{$\begin{array}{l}\text { Hospital } \\
\text { Mode of delivery }\end{array}$}} & \multicolumn{2}{|r|}{33} & \multicolumn{2}{|c|}{80.5} \\
\hline & & & & & \\
\hline \multicolumn{3}{|c|}{ Spontaneous } & \multicolumn{2}{|r|}{17} & \multicolumn{2}{|c|}{32.6} \\
\hline \multirow{2}{*}{\multicolumn{3}{|c|}{$\begin{array}{l}\text { Assisted vaginal delivery } \\
\text { Caesarean delivery }\end{array}$}} & \multicolumn{2}{|r|}{15} & \multicolumn{2}{|c|}{28.8} \\
\hline & & & & 9 & \multicolumn{2}{|c|}{17.3} \\
\hline \multicolumn{3}{|c|}{ Not delivered } & & 11 & \multicolumn{2}{|c|}{21.2} \\
\hline \multicolumn{7}{|c|}{ Time of eclampsia } \\
\hline $\begin{array}{l}\text { Fetal } \\
\text { outcome }\end{array}$ & $\begin{array}{l}\text { Ante- } \\
\text { partum }\end{array}$ & $\%$ & $\begin{array}{l}\text { Intra- } \\
\text { partum }\end{array}$ & $\%$ & $\begin{array}{l}\text { Post- } \\
\text { partum }\end{array}$ & $\%$ \\
\hline Alive & 12 & $(46.2)$ & 7 & $(38.9)$ & 4 & $(50)$ \\
\hline In utero & 9 & (34.6) & 2 & $(11.1)$ & - & - \\
\hline Stillbirth & 5 & $(19.2)$ & 9 & (50) & 4 & (50) \\
\hline
\end{tabular}

with diazepam as the anticonvulsant. Recurrence of fit was observed in three of the cases before their eventual death. Eleven of the mothers died undelivered giving a maternal mortality ratio of 279.8/100,000 deliveries, while the remaining 41 patients: 23 were live births, while 18 were stillbirths.

The relationship between fetal outcome and time of eclampsia is also shown in same Table 2; in those who experienced ante-partum eclampsia, 12 of the neonates were delivered alive, accounting for $46.2 \%$ of the live births, while intrapartum and post-partum 7 and 4 live births were found. Only 19.2 of stillbirths occurred in the ante-partum group compared to $50 \%$ in each of the intrapartum and postpartum eclamptics.

\section{Discussion}

During the 5-year study period, out of the 224 cases of eclampsia, 52 maternal deaths were recorded, giving case fatality rate of $22.3 \%$ which is significantly higher than reported in India $(7.8 \%)^{[10]}$ and other parts of Nigeria [Benin (10.7\%), ${ }^{[11]}$ Gombe $(11.6 \%),{ }^{[9]}$ Ukpoma $(15.4 \%)^{[6]}$ and Jos $\left.(16.9 \%)^{[12]}\right]$. The eclampsia-related maternal mortality ratio of $1322 / 100000$ deliveries found was however lower than reported in Uyo (6800/100000). ${ }^{[13]}$ There was no much significant difference in case fatality among the reported groups $<20,20-29$, and above 30 years with $22.1 \%, 23.8 \%$, and $26.7 \%$, respectively.

Two-third of the death were of those experiencing their first deliveries which is not unexpected because the reported incidences of eclampsia is much higher in this group of patients..$^{[9,12,14-16]}$ Almost all the mothers not had any formal education that is not surprising, as there is apathy toward western education, particularly for girls' and children education with subsequent early marriage. The poor/lack antenatal supervision in majority, who were only rushed to the hospital at terminal stages of the emergency, may account for more deaths. This was similar to findings in the Niger Delta region of Nigeria. ${ }^{[6] .}$

Because of the peculiarity of these patients (unbooked and illiterates in majority), gestational age was either estimated in months or extrapolated from the fundal height measurement at the time of examination, this often lead to problem of decision making at mode of delivery when fetal survival is to be considered. Maternal death is higher among those who experienced antepartum eclampsia compared to those who had intrapartum or post-partum eclampsia. This could be partly explained by the relatively longer duration or possibly repeated episodes of convulsion from the onset of the first fit that often increased the risk of mortality. The observed maternal mortality ratio in this study of $279.8 / 100,000$ deliveries was much higher than reported from Kaduna Nigeria of $141 / 100,000 .{ }^{[17]}$ However, there is no much significant difference between live births and stillbirths, but the stillbirth rate of $34.6 \%$ is similar to findings in Jos of $31.7 \% .^{[12,16,18]}$

Compared to those with other forms of eclampsia, neonatal outcome is relatively better among those with antepartum eclampsia; this might not be unconnected with the earlier recourse to caesarean section that might tend to minimiz further risks to both the mother and the fetus from repeated convulsions and its consequences.

\section{Conclusion}

Eclampsia no doubt contributes significantly to maternal mortality in Nigeria, more so in our geopolitical zone. Effort should be made by all concern to improve facilities and social infrastructures that will directly or otherwise minimize the occurrence of eclampsia. Skilled and prompt attendant of patient in emergency situations will help to curtail mortalities from preventable morbidities.

\section{References}

1. Ogunbode 0 . Clinical aspects of eclampsia at Ibadan, Nigeria. Nigeria Med J 1997;7:162-6.

2. Obed SA, Wilson JB, Sakay A. Determinants of maternal mortality in eclampsia at Korle Bu Teaching Hospital Accra, Ghana. Ghana Med J 1999;33:86-9.

3. Duley L. maternal mortality associated with hypertensive disorders of pregnancy in Africa, Asia, Latin America and the Caribbean. Br J Obstet Gynaecol 1992;99:547. 
4. Fasubaa OB, Oguniyi SO, Ezechi OC. Maternal mortality in Obafemi Awolowo University Teaching Hospitals Complex, Ile Ife: A Comparison of maternal Deaths in young and the older women. NigerJ Med 1999;8:147-51.

5. Briggs ND. Maternal mortality in Sub Saharan Africa: The problems and prevention. Trop J Obstet Gynaecol 1994;11:8-11.

6. Igberase GO, Ebeigbe PN. Eclampsia: Ten years of experience in a rural tertiary hospital in Niger Delta, Nigeria. J Obstet Gynaecol 2006;26:414-7.

7. Ozumbia BC, Ibe Al. Eclampsia in Enugu eastern Nigeria. Acta Obstet Gynaecol Scand 1993;72:189-92

Page $\mid 84$

8. Yusuf MA, Hamisu MS, Nalini SK, Greg RA. Maternal mortality in northern Nigeria: A population based study. EurJ Obstet Gynaecol Reprod Biol 2003;109:153-7.

9. El- NafatyAU, Melah GS, Massa AA, Audu BM, Madziga N. The analysis of Eclamptics morbidity and mortality in the Specialist Hospital Gombe, Nigeria. J Obstet Gynaecol 2004;24:142-7.

10. Raksha A, Gangul, RP, Swain S, Oumachiqul, Raja Ram P. Determinants of maternal mortality in eclampsia in India. Australian NZJ Obstet Gynaecol 1994;34:537-9.

11. Onuh SO, Aisien AO. Maternal and Fetal in eclamptics patients in Benin City, Nigeria. J Obstet Gynaecol 2004;24:765-8.
12. Ujah IA, Aisien OA, Mutihir JT, Vanderjagt DJ, Glew $\mathrm{RH}$, Uguru VE. Maternal mortality among adolescent women in Jos, North Central, Nigeria. J Obstet Gynaecol 2005;25:3-6.

13. Bassey $A E$, Abasiatai $A M$, Umoiyoho AJ, Udoma EJ. Presentation and outcome of eclampsia in Uyo, SouthSouth Nigeria. Trop J Med Res 2005;9:9-11.

14. Ikechebelu JI, Okoli CC. Review of eclampsia at the Nnamdi Azikiwe University Teaching Hospital, Nnewi. J Obstet Gynaecol 2002;22:287-90.

15. Ogunniyi SO. Eclampsia a continuing obstetrics catastrophe, the experience in Ile Ife, Nigeria. J Obstet Gynaecol 1999;19:26-9.

16. Onwuhafua PI, Onwuhafua A, Adze J, Mairami Z. Eclampsia in Kaduna state of Nigeria: A proposal for a better outcome. Niger J Med 2001;10:81-4.

17. Onwuhafua PI. Dying undelivered. J Obstet Gynaecol 2002;22:155-8.

18. Onwuhafua PI, Oguntayo A. Perinatal mortality associated with eclampsia in Kaduna, Northern Nigeria. Niger J Med 2006;15:397-400.

Source of Support: Nil, Conflict of Interest: None declared.

\section{Author Help: Reference checking facility}

The manuscript system (www.journalonweb.com) allows the authors to check and verify the accuracy and style of references. The tool checks the references with PubM ed as per a predefined style. Authors are encouraged to use this facility, before submitting articles to the journal.

- The style as well as bibliographic elements should be $100 \%$ accurate, to help get the references verified from the system. Even a single spelling error or addition of issue number/month of publication will lead to an error when verifying the reference.

- Example of a correct style

Sheahan P, O'leary G, Lee G, Fitzgibbon J . Cystic cervical metastases: Incidence and diagnosis using fine needle aspiration biopsy. Otolaryngol Head Neck Surg 2002;127:294-8.

- Only the references from journals indexed in PubM ed will be checked.

- Enter each reference in new line, without a serial number.

- Add up to a maximum of 15 references at a time.

- If the reference is correct for its bibliographic elements and punctuations, it will be shown as CORRECT and a link to the correct article in PubM ed will be given.

- If any of the bibliographic elements are missing, incorrect or extra (such as issue number), it will be shown as INCORRECT and link to possible articles in PubM ed will be given. 